\title{
Digitalization of Learning Media through Digital Book Development Using the Flipbook Application
}

\author{
Meylani Astino Perdana1, Dodiet Enggar Wibowo², Mochamad Kamil Budiarto ${ }^{3 *}$ iD \\ ${ }^{I}$ Teknologi Pembelajaran, Fakultas Ilmu Pendidikan, Universitas Negeri Yogyakarta, Yogyakarta, Indonesia \\ ${ }^{2}$ Pendidikan Guru Sekolah Dasar, Fakultas Ilmu Pendidikan, Universitas Negeri Yogyakarta, Yogyakarta, Indonesia \\ ${ }^{3}$ Teknologi Pendidikan, Fakultas Keguruan dan Ilmu Pendidikan, Universitas Sebelas Maret, Indonesia \\ *Corresponding author: kamilbudiarto@gmail.com
}

\section{Abstract}

The development and advancement of information and communication technology that penetrates various fields of human life had enormous potential to be used, therefore it was important to integrate thoroughly between technology into the learning process. This study aims to develop a flipbook-based digital as an instructional media that was suitable for the learning activities. This research approach was research and development (RnD) with the ADDIE as a development model which consists of Analysis, Design, Development, Implementation, Evaluation. However, this research only focuses on knowing the feasibility level of the flipbook. The subjects of this study were media experts ( 2 people), material experts ( 2 people), subject teachers (4 people), and 44 high school class XI Science students. The research instrument used a Likert scale of 1 - 5 to find out the opinions of each validator of the flipbook as instructional media. The results of assessment from each validator will be analyzed descriptively using a percentage to determine the level of feasibility. The results showed that the flipbook-based digital media was included in the category of "feasible" to be used as an instructional learning media for biology class in high school, this was indicated by the results of the validation by each of the validators who obtained a "feasible" result.

Keywords: feasibility; flipbook; interactive; learning activities

\begin{tabular}{lll}
\hline History: & & Publisher: Undiksha Press \\
Received & : April 24, 2021 & Licensed: This work is licensed under \\
Revised & : April 28, 2021 & a Creative Commons Attribution 3.0 License \\
Accepted & : May 22, 2021 & CC (D) (O) \\
Published & : July 25, 2021 &
\end{tabular}

\section{INTRODUCTION}

The development and advancement of industry and technology also play a role in creating a learning environment. As can be seen today, the world has entered the era of industrial revolution 4.0, where every aspect of human life has been integrated with technology systems and algorithms, for example, usage of computers, smartphones, the internet, and cloud-based technology (Chen \& Tsai, 2021; Oke \& Fernandes, 2020; Vernadakis et al., 2012). The educational aspect was one of the aspects influenced by industry 4.0; this was indicated by the digitalization and modernization of learning facilities that were becoming available in various educational institutions in Indonesia (Shahroom \& Hussin, 2018; Li, 2020; Willya et al., 2019). The presence of various digital-based platforms in the educational aspect will open up opportunities for the use of technology, create a more dynamic learning atmosphere, and has a high level of accessibility (Eze et al., 2018; Sert \& Boynueğri, 2017). Thus, the use of integrated technology between subject matter, learning support devices, and learning support tools can be one factor that determines students' success in mastering various kinds of competencies (Bdiwi et al., 2019; Kurtz, Tsimerman, \& Steiner, 2014).

The success and success of students in achieving a learning goal cannot be separated from the contribution of various supporting factors such as learning media, materials, learning environment, teacher competence, and learning facilities (Kivunja, 2015; Kristinawati, Susilo, \& Gofur, 2018; Shetu et al., 2021). As mentioned, learning media is one 
factor contributing to the achievement of learning objectives (Puspitorini, Subali, \& Jumadi, 2014; Sunismi, 2015). Along with the development and advancement of learning media technology, instructional has increased from various sides, balanced with its usefulness in the world of education (Sayıner \& Ergönül, 2021; Shetu et al., 2021). However, the facts in the field still show that some educational institutions are still quite resistant to learning methods that tend to be conventional and cannot accept the presence of technology in the learning space (Ayuni, Kusmariyatni, \& Japa, 2017; Dewi, Kristiantari, \& Ganing, 2019). The tendency of educational institutions to reject the presence of technology in the learning process can be seen from teachers who still convey through lecture learning methods that tend to be one-way, using print modules as a learning support tool (Fitrisia \& Jalinus, 2019; Satriani, 2018). In addition, one of the views of educators who tend to refuse to use technology can also be seen through the results of a search on teacher competence in the field of information and communication technology which is still below average (Rivalina, 2014).

The low ability of teachers in mastering information and communication technology is also reflected in the results of observations made during learning activities; this observation takes place in class XI of high school. The observations showed that teachers tend only to deliver subject matter using books or printed modules, and they rarely use interactive digital learning media. In addition, during the learning process, the teacher only delivered material orally, which had a one-way tendency with the lecture method on some material. After being explored more deeply to the subject teacher, the use of the lecture method was motivated by the characteristics of the material presented because not all subject matter was delivered in an interactive lecture but through presentations by students and guided discussions in class, regarding the use of digital media that has been used by teachers, namely PowerPoint-based material presentation media, as well as showing videos that support the material where the video is taken through the YouTube website. Therefore, the facts that occur in the field show that in the world of education, they still cannot accept and keep up with technological developments and advances in some aspects of the support for the learning system.

As an intermediary tool used by educators in delivering subject matter, learning media has various benefits including, media as a learning resource, having a manipulative function where the learning media can load back an event in various ways that are adjusted to any circumstances, objectives, and also in any conditions according to the audience characteristics (Andriyani \& Suniasih, 2021; Buchori, Rahmawati, \& Wardani, 2017). In addition, the existence of instructional media can become an innovative solution to overcome the teacher's limitations of space and time, and it would make the teachers not have to spend much time explaining the subject matter to students (Puspitarini \& Hanif, 2019; Wulandari, 2020). Responding to problems that occur in the field with the hope that there will be an improvement from the quality of learning in senior high schools, especially in biology, and innovation needs to be implemented, one of which can be the development of flipbook-based digital learning media. Flipbook-based interactive digital books are innovative learning media in the digital era (Rusli \& Antonius, 2019; Arifin \& Lestari, 2020). Flipbooks as digital learning media will later contain materials presented in various media types, such as text, images, and video support regarding learning materials. In addition, several studies on the benefits of flipbooks in the learning process have been empirically proven to contribute to the achievement of learning objectives and increase student academic achievement (Diani \& Niken, 2018; Weng, Otanga, Weng, \& Cox, 2018).

The findings of previous research stated that the flipbook-based electronic module had successfully passed the validation test phase with excellent results, worthy of being used as a medium for learning in the classroom and increasing students' enthusiasm for learning (Riyanto et al., 2020; Susanti, Yennita, \& Azhar, 2020). Other research findings also state 
that flipbook-based electronic modules can improve student learning outcomes (Nordin, 2015; Pramana, Jampel, \& Pudjawan, 2020). There is no in-depth study on the development of digital books using flipbook applications for high school students. Therefore, developing digital learning media in flipbook format is crucial to support learning in high school. The purpose of this research is to develop digital using a flipbook application for high school students. Expecting learning media can provide stimulation to students to be more active in learning and provide the possibility for students to learn according to their learning style.

\section{MATERIALS AND METHODS}

This research is a type of research and development $(\mathrm{RnD})$. This study adopts the ADDIE development model, an acronym for Analysis, Design, Development, Implementation, Evaluation (Pramana et al., 2020). The selection of the ADDIE model is considered very suitable for creating learning products. However, this study only aims to determine the feasibility level of the product being developed. As an effort to determine the feasibility level of the product, the instrument used was a questionnaire containing questions about the feasibility of a learning media; the scoring interpretation refers to a Likert scale of 1 to 5 with very poor (1), less (2), sufficient criteria (3), good (4), and very good (5) (Sugiyono, 2018). Meanwhile, the subjects of this study were media expert validators, material expert validators, teachers, and one class of high school students totaling 44 people. The methods used to collect data are observation, interviews, and questionnaires. The instrument used to collect data is a questionnaire. From the questionnaire results, the data will be analyzed based on each respondent, using data analysis techniques. The data analysis was used to determine the feasibility level of instructional media products, which was a flipbook using percentage descriptions and categorization. The following is a descriptive data analysis using a percentage referring to (Arikunto, 2010; Bustanil S et al., 2019; Anwari et al., 2020).

Table 1. Product Feasibility criteria

\begin{tabular}{ccc}
\hline Range & Category & Decision \\
\hline $81 \%-100 \%$ & Very Good & Feasible \\
$61 \%-80 \%$ & Good & Inadequate \\
$41 \%-60 \%$ & Enough & Not Feasible \\
$21 \%-40 \%$ & Less & \\
$<20 \%$ & Not Good & \\
\hline
\end{tabular}

\section{RESULTS AND DISCUSSION}

Validation was intended to determine the level of assessment of the product being developed. In this study, the results of validation by media experts, material experts, teachers, and students will be important points for the results and discussion. The following were the development and implementation stages of the ADDIE development model, which aims to determine the feasibility level of media products. Based on the results of data analysis, media expert I and media expert II provide an overall assessment of the feasibility of a product. The results of the product feasibility assessment by the media expert, I obtained a percentage score of $94.7 \%$, which, if cited in table 1, was included in the 'feasible' category. Meanwhile, the assessment by media expert II obtained a percentage score of $96.8 \%$, which is included in the 'feasible' category. So, based on the results of the assessment of media expert I and media expert II, it shows that the product developed, a flipbook-based digital learning media, is in the 'feasible' category and can be continued at the next test stage. 
A material expert carries out the following product assessment. Based on the results of data analysis, the material presented in the learning media product is in a suitable category. This can be identified through the results of the product feasibility assessment by material expert I, who obtained a percentage score of $92.3 \%$, is included in the 'feasible' category. Furthermore, for the assessment by material expert II obtained a percentage score of $89.2 \%$, which is included in the 'feasible' category. So, based on the results of the assessment of material expert I and material expert II, it shows that the product developed, namely digital learning media based on flipbooks, can be accounted for quality and actuality so that it gets a 'feasible' category and can be continued at the following testing stage.

The implementation and evaluation stages inherent in the ADDIE model will be carried out simultaneously, with the steps for the activities as follows, media that have been developed and validated by media experts and material experts will be prepared for the implementation of feasibility evaluation as learning media by teachers and high school students as a potential user of the product. As practitioners in implementing learning, the teacher plays a role in assessing media products, whether the media being developed is suitable for use or not. The following are the results of the flipbook product feasibility assessment by four high school Biology subject teachers. The results of the assessment carried out by the subject teacher are enthusiastic in providing an assessment. In detail, the table informs that teacher I assessed $80 \%$, teacher II gave a total of $91.1 \%$, teacher III gave $88.9 \%$, and teacher IV assessed $90 \%$. Based on the assessment results, it can be concluded from teachers I, II, III, and IV that the flipbook-based digital learning media for biology subjects are included in the 'feasible' category. These results can be used as a basis for carrying out user trials for class XI Science students.

The results of the assessment carried out by the subject teacher are enthusiastic in providing an assessment. In detail, the table informs that teacher I assessed $80 \%$, teacher II gave a total of $91.1 \%$, teacher III gave $88.9 \%$, and teacher IV assessed $90 \%$. Based on the assessment results, it can be concluded from teachers I, II, III, and IV that the flipbook-based digital learning media for biology subjects are included in the 'feasible' category. These results can be used as a basis for carrying out user trials for class XI Science students.

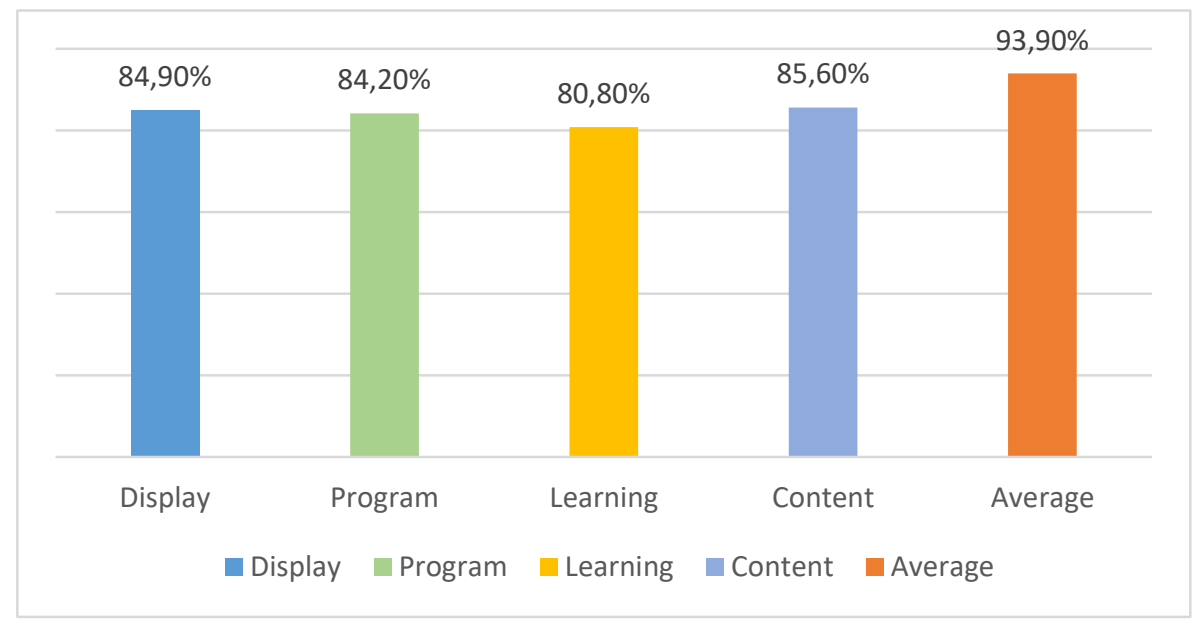

Picture 1. Results of the Media Feasibility Assessment by Students

The results of 44 students' responses to flipbook-based digital media were obtained through field trials. The detailed assessment results show that in the display aspect, a score of $84.90 \%$ was obtained, followed by the programming aspect of $84.20 \%$, the learning aspect got a score of $80.80 \%$ and the material aspect received a score of $85.60 \%$, which overall from the results of each - Each of these aspects obtained an average percentage of $93.30 \%$. These 
results indicate that the flipbook-based digital learning media product is in the 'feasible' category to be used as a learning medium in the classroom. The feasibility of a product in the form of a biology Flip Book for Senior High School class XI Science on the body defense system material is tested through validation by experts consisting of media experts and material experts, then by subject teachers, and assessments by students as users on field trials. Overall, the validation results show that the product developed is declared feasible and meets the standards of interactive multimedia in the form of a digital book (flipbook) that can be used as a learning medium.

This study has also proven empirically that the results of the developed media will meet the needs of a tool or media to facilitate students in a subject matter. This research resulted in a framework and rationale that teachers should not close themselves off from technological developments and advances. This is because technology has a tremendous opportunity to be utilized and integrated into the learning process. In addition, through this research, it was also identified that the learning process, which tends to be monotonous and one-way, is no longer suitable to be applied. Technology must begin to play a role in creating a dynamic and interactive learning atmosphere (Azizah, Khuzaemah, \& Rosdiana, 2017; Rastati, 2018). This is in line with the results of research, which states that choosing suitable media will have an optimal impact on achieving goals and increasing student motivation (Bahari, Darsana, \& Putra, 2018; Diarta et al., 2021; Prabaningrum \& Putra, 2019). The flipbook-based digital media used is following the characteristics of the students. Besides that, there are interactive elements possessed by this flipbook. Media, according to student characteristics, are very suitable for learning media (Arum \& Yuanta, 2019; Ompi, Sompie, \& Sugiarso, 2020; Tegeh, Simamora, \& Dwipayana, 2019). Therefore, through the development of digital media, it is expected to be able to provide implications for students to more easily understand the material presented using interactive digital media (Primamukti \& Farozin, 2018).

The assessment that showed positive results could not be separated from the elements inherent in the product being developed, this is as expressed by several opinions that interactive media containing multimedia elements must meet several criteria including, following the results of identification of needs, can provide motivation and attract students' attention, because it is multi-component, the media must consist of two or more components, and be able to package information or subject matter to be more interesting (Feifer \& Tazbaz, 1997; Kalyuga, 2012; Lauc et al., 2020). In addition, the design of instructional media products is essential for the developer to pay attention to. The color combination used in a learning media will attract students' attention in following the learning process (Masturah, Mahadewi, \& Simamora, 2018; Sujarwo \& Oktaviana, 2017). Several studies also show that flipbooks as books or electronic modules have a role in improving students' cognitive abilities which then have implications for increasing students' academic achievement (Rusli \& Antonius, 2019; Setiawan, Dasna, \& Muchson, 2020). Flipbook is a multimedia alternative to support the learning process can provide more flexible access for students to learn based on their learning style, which then has implications for the construction of new knowledge and improving student academic achievement (Weng et al., 2018; Rusli \& Antonius, 2019; Arifin \& Lestari, 2020).

The interpretation of the score from the material expert validation also shows that flipbook as multimedia has excellent results. Of course, it cannot be separated from the components in aspects of learning and content that already meet the standards of a subject matter (Imansari \& Sunaryantiningsih, 2017; Mayer, 2017). This is what causes flipbooks to play an optimal role in presenting material or subject matter through explanations of students' concepts, skills, and attitudes. Products developed in the form of learning media that have been validated in both digital and print formats can be used in the learning process if they are 
declared 'feasible' by media experts, material experts, subject teachers, and students (Anwari et al., 2020; Arifin \& Lestari, 2020; Ristanto et al., 2020; Tambunan et al., 2020). Overall, this flipbook-based digital learning media contains materials that have been adapted to essential competencies and learning objectives. In addition, the delivery of material composed of components of text, audio, video, pictures, and practice questions in making this digital book is expected to provide comprehensive benefits in helping students achieve learning goals.

Therefore, several studies show that the application of flipbooks as a representative form of interactive multimedia learning media can increase student interest in participating in the learning process (Lauc et al., 2020; Wulandari, 2020), improve academic achievement including student cognitive learning outcomes (Primamukti \& Farozin, 2018; Weng et al., 2018; Hanif, 2020), and as multimedia contribute to shaping the personality and character of students (Komalasari \& Rahmat, 2019; Prasetyo et al., 2020; Indah Septiani et al., 2020). Flipbook development as a learning tool has limitations, including being limited to specific subjects and topics. The use of flipbook products still requires a computer or laptop. This research is limited to product development and feasibility testing, not to measure product effectiveness products with certain measurement variables. Students in an independent study can use this developed flipbook to improve student learning outcomes.

\section{CONCLUSION}

The development of digital and interactive media products for the learning process has a critical role in supporting creating a learning environment in the appropriate category of learning media. Can the key that this flipbook-based digital media is suitable for use in the learning process. It is recommended for teachers to use digital and interactive media products to make it easier for students to learn.

\section{REFERENCES}

Andriyani, N. L., \& Suniasih, N. W. (2021). Development Of Learning Videos Based On Problem-Solving Characteristics Of Animals And Their Habitats Contain in Science Subjects On 6th-Grade. Journal of Education, 5(1), 37-47. http://dx.doi.org/10.23887/jet.v5i1.32314.

Anwari, T., Shodiqin, A., \& Priyolistiyanto, A. (2020). Pengembangan Media Pembelajaran Berbasis Android Pada Pemrograman Dasar Pascal. Jurnal Penelitian Dan Pengembangan Pendidikan, 4(1), 123. https://doi.org/10.23887/jppp.v4i1.24782.

Arifin, A. syamsul, \& Lestari, E. S. (2020). Genetics bacterial teaching materials development based on flipbook in microbiology subject to improve learning motivation. JPBIO (Jurnal Pendidikan Biologi), 5(2), 202-211. https://doi.org/10.31932/jpbio.v5i2.862.

Arikunto, S. (2010). Prosedur Penelitian Ilmiah. In Rineka cipta, Jakarta.

Arum, R. A. S., \& Yuanta, F. (2019). Pengaruh Media Pop-Up Book Terhadap Hasil Belajar Siswa Sekolah Dasar Tema Indahnya Keragaman Di Negeriku. Prosiding Seminar Nasional Cendekiawan, 2. https://doi.org/10.25105/semnas.v0i0.5875.

Ayuni, I. A. S., Kusmariyatni, N., \& Japa, I. G. N. (2017). Pengaruh Model Pembelajaran Talking Stick Berbantuan Media Question Box Terhadap Hasil Belajar IPA Kelas V. Journal of Education Technology, 3(1). http://dx.doi.org/10.23887/jet.v1i3.12503.

Azizah, S., Khuzaemah, E., \& Rosdiana, I. (2017). Penggunaan Media Internet eXe-Learning Berbasis Masalah pada Materi Perubahan Lingkungan untuk Meningkatkan Hasil Belajar Siswa dalam kehidupan sehari-harinya dan juga psikomotor ( keterampilan ) 
siswa . Proses belajar dapat materi dan bahan belajar yang. Scientiae Educatia: Jurnal Pendidikan Sains, (2005), 197-213. http://dx.doi.org/10.24235/sc.educatia.v6i2.1957.

Bahari, Darsana, \& Putra. (2018). Pengaruh Model Discovery Learning Berbantuan Media Lingkungan Alam Sekitar terhadap Hasil Belajar IPA. Jurnal Ilmiah Sekolah Dasar, 2(2). https://doi.org/10.23887/jisd.v2i2.15488.

Bdiwi, R., de Runz, C., Faiz, S., \& Cherif, A. A. (2019). Smart learning environment: Teacher's role in assessing classroom attention. Research in Learning Technology, 27, 1-14. https://doi.org/10.25304/rlt.v27.2072.

Buchori, Rahmawati, S., \& Wardani, S. (2017). The Development of A Learning Media for Visualizing the Pancasila Values Based on Information and Communication Technology. Jurnal Cakrawala Pendidikan, 36(3), 502-521. https://doi.org/10.21831/cp.v36i3.12748.

Bustanil S, M., Asrowi, \& Adianto, D. T. (2019). Pengembangan Media Pembelajaran Interaktif Berbasis Video Tutorial Di Sekolah Menengah Kejuruan. JTP - Jurnal Teknologi Pendidikan, 21(2), 119-134. https://doi.org/10.21009/jtp.v21i2.11568.

Chen, C.-H., \& Tsai, C.-C. (2021). In-service teachers' conceptions of mobile technologyintegrated instruction: Tendency towards student-centered learning. Computers \& Education, 170(1). https://doi.org/10.1016/j.compedu.2021.104224.

Dewi, N. N. K., Kristiantari, M. . R., \& Ganing, N. N. (2019). Pengaruh Model Pembelajaran Picture And Picture Berbantuan Media Visual Terhadap Keterampilan Menulis Bahasa Indonesia. Journal of Education Technology, 3(4). http://dx.doi.org/10.23887/jet.v3i4.22364.

Diani, R., \& Niken, S. H. (2018). Flipbook Berbasis Literasi Islam : Pengembangan Media Pembelajaran Fisika dengan 3d Pageflip Professional Flipbook Based On Islamic Literacy: The Development Of Physics Learning Media Using 3d Pageflip Professional." 4(2):234-44. Jurnal Inovasi Pendidikan IPA, 4(2). https://doi.org/10.21831/jipi.v4i2.20819.

Diarta, F., Tiara, Kantun, S., \& Sari, D. E. (2021). The effectiveness of the digital books' usage to improve the XII IPS 3 class students' motivation at SMAN Pakusari Jember. IOP Conference Series: Earth and Environmental Science, 747(1), 012101. https://doi.org/10.1088/1755-1315/747/1/012101.

Dinayusadewi, N. P., Ngurah, G., \& Agustika, S. (2020). Development Of Augmented Reality Application As A Mathematics Learning Media In Elementary School Geometry Materials. Journal of Education Technology, 4(2), 204-210.

Eze, S. C., Chinedu-Eze, V. C., \& Bello, A. O. (2018). The utilisation of e-learning facilities in the educational delivery system of Nigeria: a study of M-University. International Journal of Educational Technology in Higher Education, 15(1). https://doi.org/10.1186/s41239-018-0116-z.

Feifer, R. G., \& Tazbaz, D. (1997). Interface design principles for interactive multimedia. Telematics and Informatics. https://doi.org/10.1016/s0736-5853(96)00018-4.

Fitrisia, R., \& Jalinus, N. (2019). Komparasi Penggunaan Modul Cetak dengan Multimedia Interaktif Terhadap Hasil Belajar Ditinjau dari Kreativitas Siswa. INVOTEK: Jurnal Inovasi Vokasional Dan Teknologi, 19(2), 67-74. https://doi.org/10.24036/invotek.v19i2.307.

Hanif, M. (2020). The development and effectiveness of motion graphic animation videos to improve primary school students' sciences learning outcomes. International Journal of Instruction, 13(4), 247-266. https://doi.org/10.29333/iji.2020.13416a.

Imansari, N., \& Sunaryantiningsih, I. (2017). Pengaruh Penggunaan E-Modul Interaktif Terhadap Hasil Belajar Mahasiswa Pada Materi Kesehatan dan Keselamatan Kerja. VOLT: Jurnal Ilmiah Pendidikan Teknik Elektro, 2(1), 11-16. 
http://dx.doi.org/10.30870/volt.v2i1.1478.

Indah Septiani, A. nisa N. S., Septiani, I., Rejekiningsih, T., Triyanto, \& Rusnaini. (2020). Development of interactive multimedia learning courseware to strengthen students' character. European Journal of Educational Research, 9(3), 1267-1279. https://doi.org/10.12973/eu-jer.9.3.1267.

Kalyuga, S. (2012). Interactive distance education: A cognitive load perspective. Journal of Computing in Higher Education. https://doi.org/10.1007/s12528-012-9060-4.

Kivunja, C. (2015). Unpacking the Information, Media, and Technology Skills Domain of the New Learning Paradigm. International Journal of Higher Education, 4(1). https://doi.org/10.5430/ijhe.v4n1p166.

Komalasari, K., \& Rahmat, R. (2019). Living Values Based Interactive Multimedia in Civic Education Learning. International Journal of Instruction, 12(1), 113-126. https://doi.org/10.29333/iji.2019.1218a.

Kristinawati, E., Susilo, H., \& Gofur, A. (2018). ICT Based-Problem Based Learning on Students' Cognitive Learning Outcomes. Jurnal Pendidikan Sains, 6(2), 38-42. http://dx.doi.org/10.17977/jps.v6i2.11683.

Kurtz, G., Tsimerman, A., \& Steiner, O. (2014). The Flipped Classroom Answer to Future Learning? European Journal of Open, Distance and E-Learning, 17(2). https://doi.org/10.2478/eurodl-2014-0027.

Lauc, T., Jagodić, G. K., \& Bistrović, J. (2020). Effects of Multimedia Instructional Message on Motivation and Academic Performance of Elementary School Students in Croatia. International Journal of Instruction, 13(4), 491-508. https://doi.org/10.29333/iji.2020.13431a.

Li, L. (2020). Education supply chain in the era of Industry 4.0. Systems Research and Behavioral Science, 37(4), 579-592. https://doi.org/10.1002/sres.2702.

Masturah, E. D., Mahadewi, L. P. P., \& Simamora, A. H. (2018). Pengembangan Media Pembelajaran Pop-Up Book pada Mata Pelajaran IPA Kelas III Sekolah Dasar. Jurnal EDUTECH Universitas Pendidikan Ganesha, 6(2), 212-221. http://dx.doi.org/10.23887/jeu.v6i2.20294.

Mayer, R. E. (2017). Using multimedia for e-learning. Journal of Computer Assisted Learning, 33(5), 403-423. https://doi.org/10.1111/jcal.12197.

Nordin, J. M. (2015). Improving Bedside Communication and Promoting Patient-Centered Care through the Development and Use of Translation Flipbooks. Biology of Blood and Marrow Transplantation, 21(2). https://doi.org/10.1016/j.bbmt.2014.11.655.

Oke, A., \& Fernandes, F. A. P. (2020). Innovations in Teaching and Learning: Exploring the Perceptions of the Education Sector on the 4th Industrial Revolution (4IR). Journal of Open Innovation: Technology, Market, and Complexity, 6(2), 31. https://doi.org/10.3390/joitmc6020031.

Ompi, Sompie, \& Sugiarso. (2020). Video animasi interaktif 3d dampak penggunaan gadget pada anak sekolah dasar tingkat awal. Jurnal Teknik Elektro Dan Komputer, 9(2). https://doi.org/10.35793/jtek.9.2.2020.29717.

Prabaningrum, I. G. A. I., \& Putra, I. K. A. (2019). Pengaruh Model Pembelajaran Kooperatif Team Assisted Individualization Berbantuan Media Semi Konkret Terhadap Kompetensi Pengetahuan Matematika. Jurnal Ilmiah Sekolah Dasar, 3(4), 414. https://doi.org/10.23887/jisd.v3i4.21775.

Pramana, Jampel, \& Pudjawan. (2020). Meningkatkan Hasil Belajar Biologi Melalui EModul Berbasis Problem Based Learning. Jurnal Edutech Undiksha, 8(2), 18-32. http://dx.doi.org/10.23887/jeu.v8i2.28921.

Prasetyo, G., Hidayatullah, M. F., Akhyar, M., Wiranto, \& Perdana, R. (2020). Strengthening Students' Character Through Multimedia Learning In Primary Schools Education: 
Systematic Literature Reviews. Humanities \& Social Sciences Reviews, 8(3), 268277. https://doi.org/10.18510/hssr.2020.8328.

Primamukti, A. D., \& Farozin, M. (2018). Utilization of interactive multimedia to improve learning interest and learning achievement of child. Jurnal Prima Edukasia, 6(2), 111-117. https://doi.org/10.21831/jpe.v6i2.19183.

Puspitarini, Y. D., \& Hanif, M. (2019). Using Learning Media to Increase Learning Motivation in Elementary School. Anatolian Journal of Education, 4(2), 53-60. https://doi.org/10.29333/aje.2019.426a.

Puspitorini, Subali, \& Jumadi. (2014). Penggunaan Media Komik Dalam Pembelajaran IPA Untuk Meningkatkan Motivasi Dan Hasil Belajar Kognitif Dan Afektif. Cakrawala Pendidikan, 33(3), 413-420. https://doi.org/10.21831/cp.v3i3.2385.

Rastati, R. (2018). Media Literasi Bagi Digital Natives: Persektif Generasi Z Di Jakarta. Kwangsan: Jurnal Teknologi https://doi.org/10.31800/jtp.kw.v6n1.p60--73.

Ristanto, R. H., Rusdi, R., Mahardika, R. D., Darmawan, E., \& Ismirawati, N. (2020). Digital Flipbook Imunopedia (DFI): A Development in Immune System e-Learning Media. International Journal of Interactive Mobile Technologies (IJIM), 14(19), 140-162. https://doi.org/10.3991/ijim.v14i19.16795.

Rivalina, R. (2014). Kompetensi Teknologi Informasi Dan Komunikasi Guru Dalam Peningkatan Kualitas Pembelajaran. Jurnal Teknodik, 18(2), 165-176. https://doi.org/http://dx.doi.org/10.32550/teknodik.v0i0.121.

Riyanto, R., Amin, M., Suwono, H., \& Lestari, U. (2020). The New Face of Digital Books in Genetic Learning: A Preliminary Development Study for Students' Critical Thinking. International Journal of Emerging Technologies in Learning (IJET), 15(10), 175. https://doi.org/10.3991/ijet.v15i10.14321.

Rusli, M., \& Antonius, L. (2019). Meningkatkan Kognitif Siswa SMAN I Jambi Melalui Modul Berbasis E-Book Kvisoft Flipbook Maker. Jurnal Sistem Komputer Dan Informatika (JSON), 1(1), 59. https://doi.org/10.30865/json.v1i1.1397.

Satriani, S. (2018). Inovasi Pendidikan: Metode Pembelajaran Monoton ke Pembelajaran Variatif (Metode Ceramah Plus). Jurnal Ilmiah Iqra', 10(1). https://doi.org/10.30984/jii.v10i1.590.

Sayıner, A. A., \& Ergönül, E. (2021). E-learning in clinical microbiology and infectious $\begin{array}{llll}\text { diseases. Clinical Microbiology and } & \end{array}$ https://doi.org/10.1016/j.cmi.2021.05.010.

Sert, N., \& Boynueğri, E. (2017). Digital technology use by the students and English teachers and self-directed language learning. World Journal on Educational Technology: Current Issues, 9(1), 24. https://doi.org/10.18844/wjet.v9i1.993.

Setiawan, N. C. E., Dasna, I. W., \& Muchson, M. (2020). Pengembangan Digital Flipbook untuk Menfasilitasi Kebutuhan Belajar Multiple Representation pada Materi Sel Volta. Hydrogen: Jurnal Kependidikan Kimia, 8(2), 107. https://doi.org/10.33394/hjkk.v8i2.3194.

Shahroom, A. A., \& Hussin, N. (2018). Industrial Revolution 4.0 and Education. International Journal of Academic Research in Business and Social Sciences, 8(9). https://doi.org/10.6007/IJARBSS/v8-i9/4593.

Shetu, S. F., Rahman, M. M., Ahmed, A., Mahin, M. F., Akib, M. A. U., \& Saifuzzaman, M. (2021). Impactful e-learning framework: A new hybrid form of education. Current Research in Behavioral Sciences, 2(April), 100038. https://doi.org/10.1016/j.crbeha.2021.100038.

Sugiyono, D. (2018). Metode penelitian kuatintatif, kualitatif dan R \& D. In Bandung: Alfabeta. 
Sujarwo, S., \& Oktaviana, R. (2017). Pengaruh Warna Terhadap Short Term Memory Pada Siswa Kelas VIII SMP N 37 Palembang. Psikis: Jurnal Psikologi Islami, 3(1), 33-42. https://doi.org/10.19109/psikis.v3i1.1391.

Sunismi. (2015). Developing Guided Discovery Learning Materials Using Mathematics Mobile Learning Application As An Alternative Media For The Students Calculus II. Cakrawala Pendidikan, 34(3), 334-346. https://doi.org/10.21831/cp.v3i3.7340.

Susanti, N., Yennita, Y., \& Azhar, A. (2020). Development of Contextual Based Electronic Global Warming Modules Using Flipbook Applications as Physics Learning Media in High Schools. Journal of Educational Sciences, 4(3), 541. https://doi.org/10.31258/jes.4.3.p.541-559.

Tambunan, L. R., Siregar, N. A. R., \& Susanti, S. (2020). Implementasi E-book Berbasis Smartphone pada Materi Polinomial di Kelas XI SMA Negeri 4 Tanjungpinang. Jurnal Anugerah. https://doi.org/10.31629/anugerah.v2i2.2521.

Tegeh, Simamora, \& Dwipayana. (2019). Pengembangan Media Video Pembelajaran Dengan Model Pengembangan 4D Pada Mata Pelajaran Agama Hindu. Jurnal Mimbar Ilmu, 24(2), 158-166. http://dx.doi.org/10.23887/mi.v24i2.21262.

Vernadakis, Giannous, Derri, Michalopoulos, \& Kioumourtzoglou. (2012). The impact of blended and traditional instruction in students performance. In Procedia Technology, 1(1), 439-443. https://doi.org/10.1016/j.protcy.2012.02.098.

Weng, C., Otanga, S., Weng, A., \& Cox, J. (2018). Effects of interactivity in E-textbooks on 7th graders science learning and cognitive load. Computers \& Education, 120, 172184. https://doi.org/10.1016/j.compedu.2018.02.008.

Willya, Poluakan, Dikayuana, Wibowo, \& Raharjo. (2019). Generasi Milenial Pada Era Revolusi Industri 4.0. Focus: Jurnal Pekerjaan Sosial, 2(2). https://doi.org/10.24198/focus.v2i2.26241.

Wulandari, S. (2020). Media Pembelajaran Interaktif Untuk Meningkatkan Minat Siswa Belajar Matematika Di SMP 1 Bukit Sundi. Indonesian Journal of Technology, Informatics and Science (IJTIS), 1(2), 43-48. https://doi.org/10.24176/ijtis.v1i2.4891. 